\title{
Mexican De-democratization? Pandemic, HyPER-PRESIDENTIALISM AND AtTEMPTS to Rebuild a Dominant Party System
}

\author{
¿Desdemocratización mexicana? Pandemia, hiperpresidencialismo e \\ intentos por reconstruir un sistema de partido dominante
}

\author{
GERMAN PETERSEN* \\ ITESO, México
}

\section{FERNANDA SOMUANO}

El Colegio de México

\begin{abstract}
As in almost the entire world, in Mexico 2020 was the year of the pandemic. The health and socioeconomic consequences of Covid-19 were devastating, severely impacting levels of equality and inclusiveness in the country. In terms of public contestation, hyper-presidentialism and the attempts of the governing party (Morena) to become dominant have eroded checks and balances and limited political plurality in the political system. Morena is building on the bases of the former hegemonic - the PRI - and the PRD, although it faces the hurdle of weak institutionalization - albeit within a party system that is also weak. Overall, the sum of these elements suggests a process of de-democratization in the country. The recent 2021 elections were a relative setback for Morena's attempts to become a dominant party at the federal level, particularly in the Chamber of Deputies, but Morena's political strength was strongly consolidated at the local level.
\end{abstract}

Keywords: Mexico, de-democratization, pandemic, hyper-presidentialism, dominant party.

\begin{abstract}
RESUMEN
Como en prácticamente todo el mundo, el 2020 en México fue el año de la pandemia. La consecuencias sanitarias y socioeconómicas de la Covid-19 en México fueron enormes, al incrementar los niveles de desigualdad y pobreza en el país. Con respecto a la contestación pública, el hiperpresidencialismo y los intentos de Morena por consolidarse como partido dominante han erosionado los pesos y contrapesos del sistema político, y limitado la pluralidad política. Morena construye su dominio sobre las bases del antiguo partido hegemónico —el PRI-y del PRD, aunque enfrenta como reto su debilidad institucional -en un sistema de partidos también débil. En el agregado, hay elementos que apuntan hacia una desdemocratización del sistema politico. Las elecciones de 2021 constituyeron en el plano federal un relativo freno a los intentos de Morena de convertirse en partido dominante, particularmente en la Cámara de Diputados, pero la fuerza de Morena se consolidó fuertemente a nivel local.
\end{abstract}

Palabras clave: México, desdemocratización, pandemia, hiperpresidencialismo, partido dominante. 


\section{INTRODUCTION}

As in almost the entire world, in Mexico 2020 was marked by the Covid-19 pandemic. Mexico, the second largest economy in Latin America - just after Brazil-, has been hit hard by the coronavirus, to the extent that the country is one of the most severely affected in the world as measured by the number of confirmed cases and deaths ${ }^{1}$. The pandemic has produced deep consequences not only in public health, revealing the entrenched deficiencies of the healthcare system -beginning with the lack of material and human resources-, but also in the economic and social realms.

Facing the pandemic was clearly the greatest challenge in 2020 for the relative newcomer President Andrés Manuel López Obrador (AMLO), who began his tenure on December 1, 2018. The pandemic came at a time when the Mexican economy had contracted for five straight quarters, due to factors such as the deceleration in investment and private consumption, as well as the uncertainty around the North American Free Trade Agreement (NAFTA). The Covid-19 crisis accelerated these downward economic trends, resulting in the largest GDP contraction since 1929. In the worst part of the crisis, the economy saw a steep decline of $17.0 \%$ from the first quarter of 2020 to the second. Overall, GDP fell by approximately $8.5 \%$ over the year.

The pandemic also had a massive effect on the social conditions in Mexico, despite AMLO's discursive commitment to social justice and economic equality. Between April and May 2020, 12.5 million people left the labor force, raising unemployment to $4.5 \%$. The pandemic shrank the size of the economically active population from $60.5 \%$ in February 2020 to $47.5 \%$ in April (INEGI 2020). Towards the end of the year, a partial recovery of the economy helped bring 10.2 million people back to work; however, the vast majority of those who reentered the workforce joined the informal sector.

The employment figures exemplify the extent to which working conditions have become more precarious in the country (Zaga et al. 2020). Moreover, it is very likely that the sharp fall in the economy observed in 2020 may also have an effect in 2021, due to the lack of a counter-cyclical fiscal policy and the resurgence of Covid-19 cases during the winter 2020-2021 season, which may have affected production and employment once again (Zaga et al. 2020).

Amid the severe health and socioeconomic crisis, and confronted with its consequences, AMLO decided to continue with processes he had been implementing since the beginning of his administration: centralizing decision-making in the executive, slashing the state bureaucracy, weakening autonomous centers of power, and eliminating institutions - seen as vestiges of the old, "neoliber-

1,426,094 and 125,000, respectively (Animal Político 2020), and these were allegedly massively underestimated as Mexico had one of the lowest testing rates worldwide. Excess deaths are estimated at 450,000 as of April 11, 2021 (Karlinsky and Kobak 2021). 
$\mathrm{al}^{\prime \prime}$ order - without guaranteeing the construction of new and efficient ones. A clear example is the National Institute of Health for Wellness (Insabi), created in replacement of Seguro Popular. Currently, Insabi is operating without established formal rules and with apparently insufficient funds for such an ambitious task as providing free and unrestricted medical care and medications for all beneficiaries (Flamand n.d.).

Several scholars have seen this process as the return of presidential power to unprecedented levels in Mexican democracy, considered to have begun in earnest in 2000. Certain practices recall the old presidentialism of the Partido Revolucionario Institucional (PRI). This time, however, the robust mediating institutions that stood between the executive and the masses under Mexico's dominant-party authoritarianism have no functional equivalent. The President governs with few safeguards and negligible limits to his wishes (Loaeza 2020; Sánchez-Talanquer 2020).

In this paper we question whether or not Mexico is experiencing democratic backsliding. We address this question especially through the lens of one of the dimensions of democracy put forward by Dahl (1971): public contestation. Dahl's conception of democracy as polyarchy requires that, in addition to the existence of an inclusive structure of public participation, elected government must face a considerable degree of political contestation generated by the activities of other political and social forces (Dahl 1971: 2-9; 1982: 6).

We argue that AMLO's permanent attempts to centralize power, to shield himself from scrutiny, to act unilaterally without strong oversight from the legislature, and to ensure scant control from the courts and other bodies of control, diminish contestation significantly. Despite controlling a constitutional majority in Mexico's Chamber of Deputies and an absolute majority in the Senate, the President has often chosen to work outside the formal legislative process, rallying support from the "people" to put pressure on political institutions. Moreover, AMLO has been blocking civil society organizations and restraining autonomous agencies, including the Supreme Court. The restoration of hyper-presidentialism is not a direct result of the pandemic, but the public health crisis has been an enabling environment to legitimize the President's recentralization of power to face an emergency situation.

In addition, a reconfiguration of the Mexican party system is also taking place. The system is getting closer to a dominant party regime, characterized by an increasingly hegemonic party —although institutionally weak, as we will argue further on - facing a frail and fragmented opposition. There seems to be a slow but steady rebuilding of the dominant party regime once led by the PRI, now under the leadership of the Movimiento de Regeneración Nacional (Morena) party. The reduction of pluralism implicit in a hegemonic party system also affects the level of contestation of the young Mexican democracy. 
The following sections elaborate on these different sources that may contribute to Mexico's de-democratization. We will focus mainly on those issues affecting the contestation dimension: on the one hand hyper-presidentialism, understood as presidentialism without checks and balances (Rose-Ackerman et al. 2011), and on the other, the route that Morena is taking to become a dominant party, amid a potential deinstitutionalization of the party system.

\section{DE-DEMOCRATIZATION? THREATS TO CONTESTATION AND INCLUSIVENESS}

Tilly deems a regime to be democratic "to the degree that political relations between the state and its citizens feature broad, equal, protected, mutually binding consultation" (Tilly 2007: 59). By the same standard, de-democratization becomes the process of "net movement toward narrower, more unequal, less protected, and less mutually binding consultation," which occurs more commonly during regime crises that endanger rulers and elites (Tilly 2007: 59). Dahl's (1971) classic work on the conceptualization of polyarchy describes such a regime as one "that has substantially popularized and liberalized, that is, they are highly inclusive and extensively open to public contestation" (Dahl 1971: 8). He defines polyarchy as the existence of eight institutional guarantees: freedom of organization, freedom of expression, the right to vote, broad eligibility for public office, the right to compete for support and votes, the availability of alternative sources of information, free and fair elections, and the dependence of public policies on citizens' preferences.

He also argued that these eight guarantees correspond to two underlying dimensions: contestation and inclusiveness. There is contestation when citizens "have unimpaired opportunities (...) 1. To formulate their preferences, 2. To signify their preferences to their fellow citizens and the government by individual and collective action, 3 . To have their preferences weighed equally in the conduct of the government" (Dahl 1971: 2). Inclusiveness is measured by "the proportion of the population entitled to participate on a more or less equal plane in controlling and contesting the conduct of the government" (Dahl 1971: 4).

Issues such as freedom of expression correspond to contestation since they involve unimpaired opportunities to formulate and signify preferences. The right to vote corresponds to the proportion of the population entitled to participate, or inclusiveness. Some guarantees correspond to both. For example, holding elections both allows contestation to occur and includes more of the population in important decisions (Coppedge et al. 2008).

As we already mentioned, we assess that Mexico might be transitioning to some sort of de-democratization, especially in the contestation dimension of democracy. With regards to the inclusiveness dimension, AMLO has been extremely vocal about his concerns for equality in the country. In this respect, de- 
spite the negative balance in terms of socioeconomic equality, there have been some important advances in terms of gender parity and political participation of minorities -such as indigenous people, people with disabilities, and people from the LGBT community.

The most important progress has been made towards gender equality. This has been a consequence of the pressure of social movements and civil society, which has led to institutional and legal reforms. In fact, even before AMLO came to power, Mexico has been a leader in measures to increase the participation of women in public life. By 2017, women already held more than $40 \%$ of seats in Congress, well above the OECD average of 30\% (Gurría 2020). But it was not until the 2018 election that for the first time in its history, Mexico had $48.2 \%$ of the seats in the Chamber of Deputies occupied by women, and $49.2 \%$ in the Senate.

However, the social crisis caused by the pandemic has severely affected socioeconomic inclusion. While many Latin American countries increased public debt to boost fiscal expenditure as a counter-cyclical measure in response to the economic crisis, the Mexican government took a different tack: austerity, a policy that actually preceded the pandemic (Sánchez-Talanquer 2020). According to various estimates, economic packages in Latin American countries such as Brazil, Argentina, Chile, and Peru ranged between 5\% and $10 \%$ of the GDP. In Mexico, the stimulus is estimated to be around 3\% (Bloomberg 2020; IMF 2021), including the $\$ 7.7$ billion USD ( $0.7 \%$ of its GDP) of the Emergency Prevention and Assistance Fund through which the federal government allocated additional resources to respond to the Covid-19 crisis. Though highly questioned by business groups, AMLO firmly argued that Mexico would not be issuing public debt to get out of the Covid-19 crisis, but rather would take austerity measures and reallocate resources.

The crisis deepened poverty in the country due to, among other factors, the lack of social protection mechanisms such as unemployment insurance or universal compensation policies. In 2018 the population in poverty amounted to 52.4 million people; however, according to Claudia Maldonado, member of the National Council for the Evaluation of Social Development Policy (Coneval), by May 2020 the number of people in income poverty could increase by 9.8 million due to the pandemic (OECD 2021).

Moving to the electoral front, we claim that the recent transformations of the Mexican party system, moving from a competitive three-party system -Partido Acción Nacional (PAN), PRI, and Partido de la Revolución Democrática (PRD)- to one constituted by small and medium-sized parties -with anti-ideological alliances among them- and a potential dominant party -Morena-, has negative effects on both contestation and inclusiveness because it reduces pluralism and competition. Pluralism and competition explicitly refer to contestation, since they have to do with the vote won by opposition parties, which signify preferences and give them weight in the legislative process. Yet they also have neces- 
sary implications for inclusiveness, because the "selectorate" tends to be small when nominations are not competitive and larger when they are.

\section{HYPER-PRESIDENTIALISM: INSTITUTIONAL AND CONTEXTUAL FACTORS}

Presidentialism has been defined as a form of government in which the president as the chief executive is elected by popular vote, either directly or indirectly, and both presidential and legislative terms are fixed (Mainwaring and Shugart 2002). Moreover, in pure presidentialism -as happens in Mexico-, presidents have the right to choose their own ministers, regardless of the composition of Congress.

Most of the literature that examines the strength of presidential regimes in Latin America refers to the idea that variations among countries are due to structural features, especially checks and balances between the executive, legislative and judicial branches (Negretto 2006; Penfold 2010). Some studies have added the importance of legislative support for evaluating the real power of the president (Mainwaring and Shugart 2002; Morgenstern et al. 2013). Finally, there is other literature that has emphasized that the degree of presidentialism depends on a combination of formal constitutional power and contextual factors such as the president's ability to mobilize public opinion, leadership, and the use of the media to gain approval (Hager and Sullivan 1994; Canes-Wrone 2001; Howell, 2003; Basabe-Serrano 2017).

Regarding the Mexican case, there is a similar old debate about the sources of presidential power. On the one hand, there are scholars that point to the constitutional and legal strength of the presidency and classify it as a legally-founded strong institution (Cosío Villegas 1972; Carpizo 2002). An alternative view was offered by Casar (1996), who argues that formally speaking, the Mexican presidency is relatively weak compared to those of the U.S. and other Latin American countries. Interestingly, the Mexican president has been strong in several periods, particularly during the PRI era. This apparent paradox can be explained by the informal "infiltration" of the Mexican presidents into different political institutions, such as the legislative and judiciary branches or subnational executives through the lever of the hegemonic party. In this sense, the power bases of the Mexican presidency are not constitutional, but partisan.

But, what can we say about AMLO's presidential power and why do we claim that he is moving towards hyper-presidentialism? According to Basabe-Serrano (2017), the intensity of presidentialism depends on institutional and partisan variables, and on variables related to the economic and social context in which presidents have to make decisions. Following his study, we distinguish between two different dimensions. The first includes the president's constitutional powers and the size of his legislative alliance (Mainwaring and Shugart 
2002). These elements undoubtedly affect his ability to advance his political agenda. The second has to do with contextual factors and refers to the performance of the economy as well as the approval rating of the President. These factors have an effect on the control the President has over actors and institutions that may be in competition with his political project. Clearly, when both political and contextual powers are high, the President is able to implement his agenda without major vetoes.

Regarding the first dimension, compared to the presidencies in the US and many Latin-American countries, the Mexican presidency is moderately weak in terms of constitutional powers. The president of Mexico has strong powers to shape and lead the cabinet, but his powers to influence lawmaking are relatively weak. He has the ability to appoint and remove the cabinet ministers at his discretion. He also appoints the Attorney General and the magistrates of the Supreme Court with the approval of the Senate. Nonetheless, while the president can freely dismiss the Attorney General, the magistrates of the Supreme Court have a fixed period of 15 years. In the legislative arena, the president has only a veto power that, to be overridden, requires the vote of two thirds of the members present in each chamber (Negretto 2006).

So, although he may not have very strong constitutional powers, in 2018 AMLO won the presidency with more than 50 percent of the vote, and his party (Morena) obtained 252 out of 500 seats at the Congress. For the first time since 1997, the ruling party had an absolute majority, which allowed the President to push through his reform agenda. Moreover, with their partisan allies, Morena's deputies achieved the qualified majority of two thirds necessary to modify the Constitution. Thus, they managed to carry out reforms to create the National Guard, overturn the educational reform implemented by the Peña administration, create a law on the remuneration of public servants, enact an austerity law and a new health law, as well as various institutional changes to underpin AMLO's main social programs.

Likewise, the $64^{\text {th }}$ Legislature (2018-2021) approved without changes the Expenditure Budget projects of the first three years of AMLO's government, which has allowed his administration to finance major projects, such as the Mayan Train, the Dos Bocas Refinery and the Santa Lucia Airport. Between September 2018 and April 2021, 141 reform decrees have been approved, of which 17 were to the Constitution (Cámara de Diputados 2021). Of the 35 initiatives that AMLO has sent, 27 have been approved and enacted, three are pending in commissions, and five are about to be processed in the reviewing Chamber. So, these figures show that AMLO has been able to enact a great deal of his policy agenda due to the broad legislative support he has in Congress.

Based on Basabe-Serrano (2017), contextual powers are operationalized as economic prosperity and the presidential approval rating. As we anticipated in the introduction, the Covid-19 pandemic hit Mexico while it was already in 
a frail economic situation. Data show that 2020 was the second year running in which the economy went backwards. During 2020, the Mexican economy suffered a tremendous contraction, with a drop in GDP of 8.5\% (INEGI 2020). In the ten months through October 2020, gross fixed investment was down by $19.5 \%$ compared with the same period in 2019 (INEGI 2020).

Besides the fall in the employment rate, tourism collapsed, as recessions and travel restrictions reduced travel. However, the situation in the second semester of 2020 began to improve and, according to the OECD, the Mexican economy is projected to expand by 5\% in 2021 and by 3.2\% in 2022 (OECD 2021).

However, strikingly, the economic crisis had a very slight impact on AMLO's public approval rate. According to the Oraculus poll of polls, although AMLO's popularity fell to 59\% in August 2020, it rose to 65\% at the end of December (Oraculus n.d.). Nonetheless, 56\% said he hasn't fulfilled his promises for improving the economy and 66\% said he hasn't reduced crime. The President also got more negative marks than positive in his efforts to fight corruption, combat the pandemic, and increase family income.

Thus, despite the severe economic recession and the continued violence, Mexicans hold a positive image of the President. The reason for this apparent contradiction has to do precisely with the pandemic. People perceive that the economic crisis and the non-fulfillment of AMLO's promises were due to the pandemic, not to his mismanagement (Ruiz Healy 2020). To this we must add that all the new social programs have created a base of support for the President (Buendía \& Márquez 2021). The elimination of intermediaries between the state and citizens, through the disbursement of social benefits via direct transfers, ensures that he and his party get political credit.

In summary, the combination of having a broad legislative bloc within the legislative branch, the perspectives of economic recovery, and a high approval rating have allowed the President to ignore the demands of political and social actors critical of his administration and to enact policies without needing the agreement of other legislative agents or other social and political actors.

\section{DEMOCRATIC BACKSLIDING? THE EROSION OF CHECKS AND BALANCES}

As mentioned above, since the beginning of his presidency AMLO has made clear attempts to recentralize power by limiting and disqualifying civil society and by weakening autonomous agencies, and even jeopardizing the separation of powers through his behavior towards the Supreme Court. In this section, we analyze how the antagonistic relationship between AMLO and autonomous agencies or state powers is eroding democratic checks and balances and paving the road to the restoration of hyper-presidentialism. 


\section{Civil Society}

Civil society has been seen as a means of defense against potential abuse by political leaders since the late eighteenth century. Many authors have stressed the importance of a strong and active civil society to achieve a transition to democracy and then the consolidation of a democratic regime (Tocqueville [1835], 1945; Putnam 1993; Diamond 1996). Civil society and its organizations are important counterweights to government since they monitor policies and governmental initiatives and protest when rules are infringed or promises broken. In doing so they seek to restore the public sphere and reclaim this space from vertical and even authoritarian constraints and mechanisms of control (Habermas 1991). Furthermore, civil society organizations (CSOs) have generally taken charge of many activities where the government's actions have been absent or insufficient, such as promoting environmental issues, defending human rights, addressing homelessness, etc.

When AMLO won the presidency in 2018, many CSOs believed that a new era of cooperation would start with the federal government, especially in areas that were associated with a leftist agenda (civil rights, poverty relief, environmental issues, women's claims). However, since taking office in December 2018, AMLO has clashed with a number of civil groups. AMLO has continuously denigrated civil society organizations, which he has called "useless" and "corrupt." Moreover, since the beginning of his administration, he has reiterated his decision to cancel funding for many organizations.

The first group of organizations that experienced the reduction of funding was the Red Nacional de Refugios (National Network of Shelters), 41 shelters dedicated to assisting abused women. He claimed that these organizations had been intermediaries that took advantage of resources meant to benefit the general population. In a memorandum issued on February 18, 2020, he stated that funds would no longer be transferred from the budget to social organizations. Instead, the government's support would be given directly to the beneficiaries.

In addition to state funding, civil society organizations rely on donations from private entities as well as funds generated by their own activities. AMLO, however, has simultaneously decided to eliminate incentives (tax deductibility) for private companies that make donations, meaning that civil society organizations now risk being cut off from both of their sources of outside funding. With his decision the President has threatened to end crucial collaboration with civil society. Public-private partnership for social projects is a well-known model throughout the world that takes advantage of the expertise, skill, spirit, and generosity of these organizations, so the President's decision may have very high costs for CSOs and NGOs, and therefore for democracy. 


\section{Constitutional Autonomous Agencies}

To analyze the expansion of informal presidential powers in greater detail, we examine the relationship between AMLO and two constitutional autonomous agencies (CAAs): National Electoral Institute (INE) and the National Institute for Transparency and Access to Information and Personal Data Protection (INAI).

During the first decade of the $21^{\text {st }}$ century, as Mexico gradually transitioned to democracy, the Mexican public administration undertook major civil service reforms. New regulatory agencies were set up, and those already existent were reformed, with a strong involvement of the legislature. Changes in the administrative structure included the appearance of the so-called CAAs, whose creation was supported by the idea that their actions would be based on technical criteria and a non-political logic.

On the one hand, these agencies would strengthen the regulatory capacity of the state to prevent "capture" by powerful actors; on the other, they would avoid unchecked power in the hands of the sitting president. Their creation was intended to give a professional status to certain public policy activities, which because of their nature are prone to be seized or manipulated for economic or political reasons or simply due to incompetence. Therefore, CAAs participate in a wide variety of policy areas such as central banking and monetary policy, management of elections, freedom of information and privacy, evaluation of social policy, human rights protection, etc (Pardo and Dussauge 2017).

But rather than considering CAAs as technical agencies, AMLO seems to perceive them as obstacles that hinder the actions he can undertake by means of executive decrees. In addition, both the President and his supporters believe that most autonomous bodies are expensive to maintain and have been seized by economic or political interests (Integralia 2020). Therefore, it is not surprising that AMLO has also clashed with these independent agencies by threatening to make substantial cuts to their budgets or to incorporate some of them into ministries and other federal departments. Clearly, these moves would eliminate important counterweights to government power.

A concrete example of the difficult relationship between AMLO and the CAAs has been his ongoing quarrel with the INE. The INE is an autonomous public organization that is in charge of organizing all federal and local elections. The institute was created by a constitutional reform in February 2014 to replace the erstwhile Federal Electoral Institute (IFE).

Since the beginning of his administration, AMLO has argued that the INE is a very expensive electoral body and has "never guaranteed clean and free elections" (Mexico News Daily 2020). AMLO, who claimed that fraud was the reason for his losses in the 2006 and 2012 presidential elections, said he would personally ensure that the will of the people is respected in the 2021 midterms. 
The President's remarks were interpreted by some of the institution's councilors as a sign that the autonomy of the INE was under threat.

Another confrontation between the INE and the President erupted when the former issued a preventive protection warning against AMLO on December 5, 2020, after he had repeatedly expressed his distaste for opposition parties. The INE argued a potential violation of Article 134 of the Mexican Constitution, which prohibits the president from "using public resources in favor or against a party," engaging in "personalized propaganda," or "speaking for or against any party" during government-dedicated air times. The Electoral High Court - claimed by some critics to be under the influence of Morena- determined that AMLO's actions did not deserve a warning from the INE since it was based on acts he had not yet committed.

Besides the disagreements and tensions with the INE, in several of his daily press conferences AMLO has expressed his intention to eliminate autonomous bodies. A good example is the INAI (Aristegui Noticias 2018). This CAA is responsible for upholding the right to access to the information held by any authority or agency of the executive, legislative, and judicial branches, as well as by any individual, corporation, or labor union that receives and spends public money or performs acts of authority at the federal level. The INAI is also in charge of upholding the right to protection of personal data held by the public and the private sectors. The INAI has played an important role in ensuring that Mexicans can protect their right to privacy and that journalists and human rights defenders can obtain the necessary information to document and expose human rights violations and corruption cases.

AMLO has suggested that the role of the INAI could be absorbed by government auditing agencies like the Ministry of Public Administration (Secretaría de la Función Pública), responsible for auditing the finances and performance of the executive branch of the federal government, which reports directly to the president, or the Supreme Auditing Office of the Federation (Auditoría Superior de la Federación), which is charged with auditing the use of the federal budget and reports to Congress.

However, eliminating this independent body and transferring its functions to entities that report to the executive or Congress could be a recipe for secrecy and abuse. In fact, this move would eliminate important checks and balances to government power. The role of regulators -which are among the autonomous bodies that could be affected by AMLO's plan- is to stop officials from committing acts of corruption and engaging in conflicts of interest. If they are placed under the control of government departments, their capacity to effectively oversee officials will be hamstrung (Peschard, interviewed by Mexico News Daily). ${ }^{2}$ 


\section{The Supreme Court}

Another crucial actor for democracy, which has undergone important changes since AMLO's arrival to the presidency, is Mexico's Supreme Court, which is at the top of the judicial branch. Diverse scholars and critics see the judiciary as a potential counterweight to AMLO's power that does not currently exist in Congress, since the President's agenda could have to pass through the courts at some level. The Supreme Court's main function is to defend the Federal Constitution and protect human rights. The Court is composed of eleven justices, with one being the Chief Justice (Suprema Corte de Justicia n.d.). Potentially, attempts to weaken the Court or limit its independence could be more harmful to Mexican democracy than what is happening with the CAAs, since in this case the risk would be for an entity that is much more powerful than individual agencies, not to mention a separate branch of government and the only branch of government not formally controlled by Morena.

The Supreme Court justices' 15-year terms mean that most Mexican presidents get to name at least three appointees while in office. However, halfway through his presidency, when Justice José Fernando González's term expires in 2021, AMLO will have named at least four. None of these four have been due to deaths, but due to the resignation of Justice Medina Mora -after heavy pressures from Morena- and the end of term of justices Cossío and Luna. That means that his appointees alone could limit constitutional challenges, including governmental programs, that require at least eight votes for general application.

Two of the three justices appointed by AMLO have been highly questioned by the opposition and his critics because of their close ties to the President. ${ }^{3}$ Yet, it is important to mention that there are limits to how reliable AMLO can expect his Supreme Court nominations to be. Lack of public interest, norms that grant considerable leeway to the president in making nominations, and the structure of Mexico's nominating process itself mean that the potential justices' approach to the law and constitutional interpretation are often made clear only after they are on the bench. The degree of support of the new members of the judiciary will be seen as government reform proposals reach Mexico's highest court. These may include aspects of AMLO's newly created National Guard, his large infrastructure projects, modifications to the Electricity Industry Law, and recent changes to asset forfeiture rules that give the government widespread authority to sell property seized from allegedly corrupt businesses and individuals (Russell 2019).

Though we generally pay the most attention to what happens in the Supreme Court, the President's agenda has to pass through lower courts as well. As a 
result, lower courts have become a target of AMLO's reform agenda. AMLO's allies in Congress have also played an important role in reorienting the judiciary. Legislators have presented more than 50 proposals related to the justice system since AMLO took office. Many of these changes were promoted by AMLO's party (Morena), including the elimination of state judicial councils and an extension of circumstances under which suspects can be held prior to trial. On the whole, the reforms "indicate a move toward greater centralization" said Novoa (Russell 2019).

Many observers also expect Congress to pursue a more comprehensive judicial reform during AMLO's term. If that includes proposals such as those to implement more rigorous processes for selecting judges, such a reform could help strengthen Mexico's legal institutions. But other proposals, such as a plan suggested by Morena legislators to expand the size of the Court by adding a five-member chamber dedicated to corruption crimes, could weaken judicial independence, since it would give one party the chance to name a majority of the justices on its own (Russell 2019).

\section{DÉJÁ VU? POSSIBILITIES OF ELECTORAL RECONSTRUCTION OF THE DOMINANT PARTY SYSTEM}

From an electoral viewpoint, one indicator of Mexico's possible de-democratization would be the reduction of electoral pluralism and the reconstruction of a dominant party regime derived from the deinstitutionalization of the former moderate pluralist system. In this sense, given that Mexican elections are still part of the country's normal politics, the type of de-democratization that could be taking place is the installation of what Levitsky and Way (2010) call "competitive authoritarianism," also labeled "electoral authoritarianism" (Schedler 2006).

According to these authors, in competitive authoritarianisms elections are regularly held and other aspects of democratic normality are in place-opposition parties are legal and have offices, candidates, and campaigns; opposition leaders are not persecuted-; nonetheless, at least one of the three basic features of democracy for these authors is missing: free elections, wide protection of civil liberties, and a reasonably level electoral playing field.

Regarding electoral pluralism, this has been reduced not only because of the growth of Morena, but also because the opposition parties have built electoral coalitions that have clearly reduced the options available to citizens on the ballot. As of today, there have been coalitions basically among all the opposition parties, regardless of their ideological and programmatic differences and including the former three main parties (PAN, PRI, and PRD). The largest coalitions, between the right-wing PAN and the left-wing PRD, began in gubernatorial elections in states where the PRI had never lost (Petersen 2018). Since 
then, the number of elections with coalitions as well as their size have risen to the point that PAN, PRI and PRD ran together in the 2021 midterm election in 219 of the 300 federal electoral districts.

One of the defining features of Mexican democratization is how long it took (Lujambio 2000; Merino 2003). There was no founding pact or election ( $\mathrm{O}^{\prime}$ Donnell and Schmitter 1986), as in other transitions - Spain, Argentina, Chile. In lieu of such a pact, from a national-level perspective, there was a long cycle of political and electoral reforms that gradually weakened the dominant party regime (Becerra et al. 2000). The increasing competitiveness that arose from these reforms led to the PRI's loss of the majority in the Chamber of Deputies in 1997 and of the presidency in 2000, as well as the majority in the Senate that same year. Nonetheless, a recent and widening body of literature has criticized this national-level traditional approach to the Mexican democratization, focusing on its subnational trends and revealing the persistence of authoritarian enclaves (Cornelius 1999 2000; Giraudy 2010; Martí et al. 2011; Benton 2012; Gibson 2013; Petersen 2018).

Whereas in the subnational context some authoritarian patterns persist, taken together Mexico seems to be moving backwards in electoral democracy, getting closer to the reestablishment of a dominant or hegemonic party system. According to Sartori, "a hegemonic party system is definitely not a multiparty system, but is, at best, a two-level system in which one party tolerates and discretionally allocates a fraction of its power to subordinate political groups" (Sartori 2005 [1976]: 205). Along this same line, Greene defines dominant party systems as "hybrids that combine meaningful electoral competition with continuous executive and legislative rule by a single party for at least 20 years or at least four consecutive elections" (Greene 2007: 12).

So, although it is too early to assure that the Mexican party system will become a hegemonic party system, there are some hints that point in that direction. One of them is Morena's building of its electoral base on top of the former dominant party's partisans - the priista base - and on the base of the PRD, the party where Morena originally emerged as a faction (Sonnleitner 2020). Figure 1 presents the electoral performance of Morena, the main opposition parties (PRI, PAN, and PRD, both aggregated and alone), and the sum of the smaller parties - especially PVEM, PT and MC. Considering that federal elections happen only every three years - presidential every six, midterms every three-, and therefore that federal observations are scarce, the analysis relies on state legislative elections -more or less twice the number of state executive elections-, which add up to 123 .

In particular, the figures compare the performance of the different parties or sets of parties in balanced periods before and after the foundation of Morena in 2014. Therefore, the pre-Morena period runs from 2009 to 2014 and the post-Morena period, from 2015 to 2020; 2015 was the first year in which More- 
na, using its registry as a national party, ran in state elections. The periods are balanced in number of years - six - and in number of state legislative elections - 61 pre and 62 post. As a matter of fact, the main difference in party system and electoral terms between the two periods is precisely Morena's bursting onto the scene. Although no causality can be established between Morena and the observed effects, a strong explanation-oriented inference can be achieved with this methodological design.

It should be said that each party's performance is not measured with the usual percentage of the total vote, but rather with the proportion of seats obtained in the state legislature. The reason to use this less precise measure is that the legal regulations of electoral coalitions in Mexico have varied over time. In some elections, each party appeared as a different item on the ballot, while in other elections, coalitions — not parties — appeared as a single item, meaning that the vote per party was not even registered.

Sub-figure 1 shows the impressive rise of Morena in state elections after its foundation in 2014. The 2018 election was particularly important for Morena, with the party being able to build subnationally on the "AMLO effect" - AMLO won the Presidency with an impressive $53.2 \%$ of the total vote ${ }^{4}$. Furthermore, in 2018 there was a high number of state elections, since the country tried to make as many local and state elections as possible concurrent with the federal processes. This decision unintentionally enhanced the "AMLO effect," since Morena not only performed well, but did so in an election when a massive number of public offices were in dispute.

A common explanation of Morena's rise is the demise of the former three main parties -PAN, PRI, PRD. As shown in Sub-figure 2, this is certainly the case: the aggregate subnational congressional representation of these three parties has declined over the last five years. But, what party has been the most affected electorally by the appearance of Morena?

The spatial theory of democracy (Downs 1957) would suggest that the party ideologically closest to the new party would suffer the most. In principle, this party would be the PRD. In fact, AMLO was a founder and long-time member of this party before founding Morena. Nevertheless, as shown in Sub-figure 3, the damage inflicted on the PRD is insufficient to explain the rise of Morena (Sonnleitner 2020). Certainly, the party went from a rising tendency to a clear downward trend, but the size of Morena's expansion does not correspond to the modest size of the PRD's electorate or even to the PRD's downturn.

A different development comes into view when the PRI trend is analyzed. Before the creation of Morena, from 2009 to 2014, the PRI's electoral base was not stable, but maintained a high level and grew moderately. The panorama 
changed completely at the beginning of 2015: the party's base took a brutal nosedive, which accounts for most of the three parties' demise and, more importantly, seems to account for the bulk of Morena's rapid growth. In this sense, there are elements to assert that Morena's attempt to rebuild the dominant party system has the PRI's former base as its foundation.

The PAN, much to the ideological right of Morena, followed quite similar trajectories before and after 2014. In both cases, the party took a downward path, partially explained by a better performance in midterm elections - 2009 and 2015 - than in presidential elections - 2012 and 2018 - , but also due to a steady fall throughout the respective periods.

Regarding the rest of the parties, we can say that when Morena came onto scene, their positive trend turned into a plateau. In fact, before the foundation of Morena, PVEM, PT, MC and other parties seemed to be capitalizing on an anti-systemic sentiment in certain segments of the electorate, directed at the three main parties. However, this discontent has been more effectively transformed into support for Morena since 2014.

Figure 1. Share of seats obtained in state houses
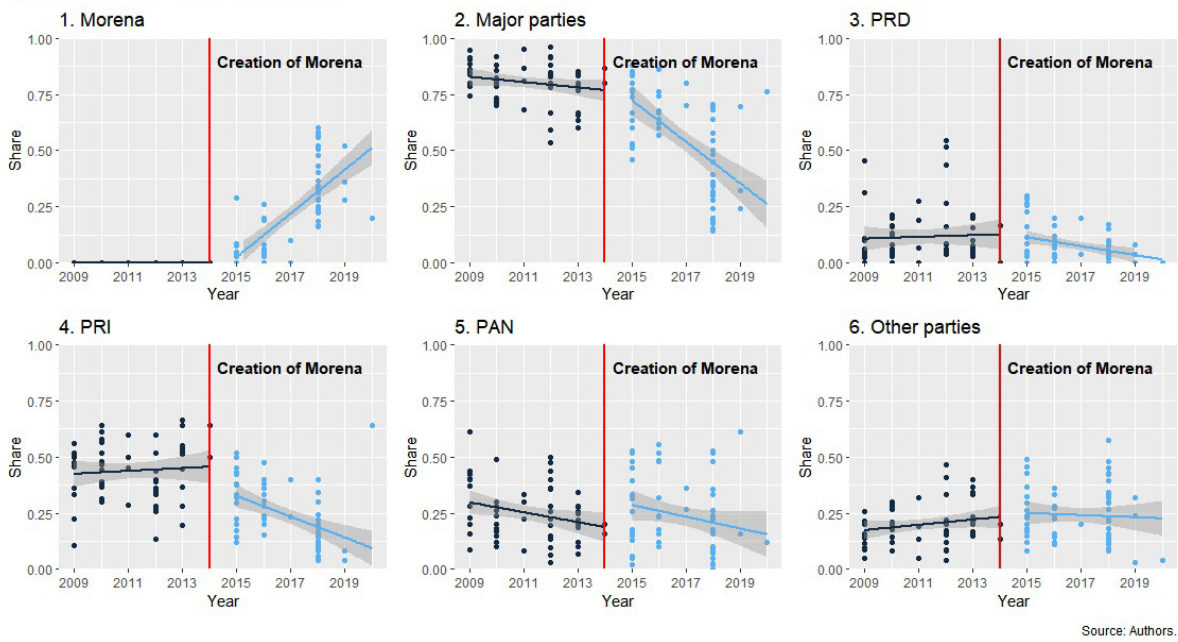

Source: Authors based on state-level electoral institutes.

A complementary angle to the above is to analyze the Mexican parties and the party system as a whole. Paradoxically, while Morena gains strength from an electoral, external perspective, internally it is as weak as the rest of the parties, and contributes to the general fragility of the Mexican party system. 


\section{A WEAK FIELD: THE DEINSTITUTIONALIZATION OF THE MEXICAN PARTY SYSTEM}

Institutionalization refers to a process by which a practice or organization becomes well established and widely known, if not universally accepted. In politics, it means that political actors have clear and stable expectations about the behavior of other actors (Huntington 1968). Mainwaring and Scully (1995) conceptualize four dimensions of party system institutionalization.

First, more institutionalized systems manifest considerable stability in patterns of party competition (Przeworski 1975). Second, in institutionalized systems, parties have strong roots in society and most voters, conversely, have strong attachments to parties. Third, in institutionalized systems, political actors confer legitimacy on parties. They see parties as a necessary part of democratic politics even if they are critical of specific parties and express skepticism about parties in general. Finally, in more institutionalized systems, party organizations are not subordinated to the interests of a few ambitious leaders and they have an independent status.

Patterns of party competition in Mexican elections reveal a certain instability. In fact, if we analyze some measures of electoral volatility, we can see how this variable has continuously changed, and increased substantially in the 2018 election.

Table 1. Electoral Volatility in Lower Chamber Mexican Elections 2000-2018

\begin{tabular}{ll}
\hline Election & Electoral volatility ${ }^{5}$ \\
\hline 2000 & 16.19 \\
2003 & 29.07 \\
2006 & 29.16 \\
2009 & 24.7 \\
2012 & 12.5 \\
2015 & 21.97 \\
2018 & 31.92 \\
\hline
\end{tabular}

Source: Palma y Osornio (2020).

Moreover, during recent decades, parties in Mexico have been perceived by citizens as the least trusted institutions, uninterested in people's demands (Latinobarómetro 2018: 53). Besides that, as a new party Morena can hardly have strong attachments in society. As noted above, Morena was not founded as a party until 2014, since earlier it was a faction of the PRD. Between 1989 and 
2014 the PRD achieved something that for decades seemed unlikely: it unified the entire left wing of Mexico's political spectrum that disputed power through electoral democracy (Bruhn 2010). The most prominent political figure of Morena, even when it was a faction of the PRD, has always been and continues to be AMLO. Like much of the leadership and membership of the PRD, AMLO was a decades-long member of the PRI. The PRI, in fact, was one of the two main sources of the PRD - the other source being the "historic" Left: socialists, communists and social democrats.

Interestingly, Morena's biggest challenge in rebuilding a dominant party system is its own institutional weakness. The party is part of the tradition of party-movements in Latin America and more particularly, of "movements that became parties" (Anria 2013; 2018). This makes Morena similar to the Bolivian Movimiento al Socialismo (MAS), the Uruguayan Frente Amplio (FA), and more classically, the Argentine Partido Justicialista (PJ) (Anria 2013, 2018; Levitsky 2003). However, in contrast with some of these party-movements, Morena has not undergone a process of intense institutionalization. Likewise, opposition parties do not have a strong institutional structure.

In 2020, Morena renewed its national leadership, after the brief interim period of Alfonso Ramírez. Since the party was unable to reach an agreement on the mechanism to elect a new leader, the Electoral High Court obliged them to make the decision based on a poll of the party's entire membership. From the beginning of the process, all Morena factions clashed, even though its internal rules forbid factions. Two candidates made it to the final stage: Mario Delgado, from the more moderate wing of the party; Porfirio Muñoz Ledo, one of the eldest members of the Mexican political elite, a former priista, founder of the PRD, relatively center-left in ideological terms, but allied with the most radical left-wing factions of Morena. Delgado won by a very narrow margin - and after several polls - he had to face Muñoz Ledo's withering critiques of the integrity of the process, which again exposed the party's internal weaknesses.

With regards to the PAN and the PRI, although they have been in the electoral arena for more than eighty years, they have suffered substantial electoral losses producing a steep drop in party membership. Whereas in $2000,24.7 \%$ of citizens identified as priistas and $25.4 \%$ as panistas, those figures moved to $16.2 \%$ and 26.2\%, respectively in 2006 (Guardado 2009). And according to the very recent Encuesta Nacional de Cultura Cívica 2020 (INEGI 2021), only 10.9\% identified with the PRI and 10.3\% with the PAN. In other words, not even together do they reach the levels of partisanship they had 20 years ago.

The PAN has undergone important internal conflicts, exacerbated in the 2018 election when the national leader, Ricardo Anaya, maneuvered to become the party's presidential candidate. Anaya's main opponents were former President Felipe Calderón and his wife, Margarita Zavala. In fact, Calderón and Zavala left the PAN and tried to create a new party, whose registration was rejected by 
the Electoral High Court in 2020. Interestingly, the High Court's decision had the unintended consequence of avoiding a fragmentation of the Right.

The PRI has maintained reasonable institutional cohesion. But despite its institutional strength, the party's original base has diminished substantially. With regards to the PRD, the fact that it was much smaller than the PRI to begin with increases the relative impact and hence, it is close to disappearing. The PRD continues to be controlled by the faction that was against AMLO when he was still a member.

There are other smaller parties, which can be categorized into two camps and none of them can claim to have strong roots in society. First, the satellite parties of Morena, such as the Partido del Trabajo (PT) and PVEM. Both parties have historically been satellites of bigger parties, the former more in the leftist camp and the latter leaning more rightward - although both of them quite pragmatic. Another party that is allied with Morena is the Partido Encuentro Solidario (PES), with an openly evangelical orientation.

Second, Movimiento Ciudadano (MC), a party allied with AMLO in 2006 and 2012, that has moved to the center of the ideological spectrum and became allied with the PAN and the PRD in 2018. In 2020, MC governed the state of Jalisco and beginning in 2021 it will govern the state of Nuevo León. In the 2021 election, MC refused to ally with other parties, trying to construct an identity as a "third way" alternative to the established opposition parties -PAN, PRI, and PRD— and to Morena.

Going back to Morena, an open question is why the party continues to be weak and divided despite the seven years that have elapsed since its foundation and when we might expect that the President could obtain political benefits from a stronger institution. One line of inquiry is that the President does not want any kind of counterweights, not even from a party that is responsive to him. This fact indicates the existence of a weak organization dominated by a personalistic leader. Weyland (2021) argues there is a "corrosive" effect of populism on Latin American parties and party systems, tendency from which Mexico is not exempt. Another possibility is that party elites have been unable to coordinate and maintain party discipline.

Another question is whether the different factions within Morena will remain inside the party despite their differences and clashes. The answer to this last question may be yes, at least until 2025, and the explanation is institutional. Mexican electoral laws allow for the creation of national parties only in the year after the presidential election. Therefore, the next time a new party can be created is 2025, after the 2024 presidential election. So, should Morena members decide to exit the party and continue participating in politics, their only option would be to move to another party, since creating a new one is a cancelled route. 
In sum, despite the possible benefits institutionalization can have in an enduring and post-charismatic leadership, Morena and its dominant elite have refused or have been unable to develop a strong party structure. This weakness, nonetheless, is not exclusive to Morena; opposition parties are equally weak. Therefore, the rebuilding of the dominant party regime is being undertaken by one party subordinated to the interests of a strong leader, within a party system constituted by opposition parties with frail structures, low legitimacy and minimal social attachments. All these elements together point to a process of deinstitutionalization of the Mexican party system overall.

\section{VII.CONCLUSION}

So, can we speak of de-democratization in Mexico? In the inclusiveness dimension, AMLO's manifest concern for social justice and economic equality contrasts sharply with the results of his administration in the context of the Covid pandemic. Poverty and inequality have risen, especially due to the decline of the employment rate, related to the lack of governmental action to implement counter-cyclical economic policies and poverty-alleviation policies. Although at the societal level there are advances of the political inclusion of women, the pandemic has set back their socioeconomic inclusion.

In terms of contestation, hyper-presidentialism and the attempts of Morena to become dominant have eroded checks and balances and limited political plurality in the political system. After the 2021 election -not covered in this paper-at the federal level AMLO's coalition (Morena-PVEM-PT) will no longer hold a qualified majority to make changes to the Constitution, although it will still hold the absolute majority. At the local level Morena and its allies strengthened their power structure, since they won 12 out of the 15 governorships that were up for election.

Moving forward, Mexico will take a long time to revert the social damages provoked by the health and economic crisis. In the institutional dimension, hyper-presidentialism could clash more violently with the country's institutional safeguards due to a larger presence of the opposition in the Chamber of Deputies. However, AMLO has in his favor Morena's building on the PRI and the PRD's bases to consolidate itself as a dominant party. The interaction between a strong President trying to dismantle checks and balances with the support of a local power structure, and an opposition that has gained strength at the federal level, seems to be among the definitive elements that will mark the fate of the Mexican political regime.

\section{REFERENCES}

Animal Político. 2020, December 31. “México cierra el 2020 con 125 mil 807 muertes por Covid y más de 12 mil casos nuevos." Retrieved 5 February 2021 from https://www. animalpolitico.com/2020/12/mexico-2020-125-mil-muertes-covid/. 
Anria, Santiago. 2013. “Social Movements, Party Organization, and Populism: Insights from the Bolivian MAS." Latin American Politics and Society 55(3): 19-46.

Anria, Santiago. 2018. When Movements Become Parties: The Bolivian MAS in Comparative Perspective. New York: Cambridge University Press.

Aristegui Noticias. 2018, December 7. “Agrandaron el gobierno con órganos autónomos como el INAI, pero creció corrupción: AMLO." Retrieved 9 July 2021 from https:/ / youtu.be/9-TjlbfTBXA.

Basabe-Serrano, Santiago. 2017. "Las distintas caras del presidencialismo: debate conceptual y evidencia empírica en dieciocho países de América Latina." Revista Española de Investigaciones Sociológicas 157: 3-22.

Becerra, Ricardo, Pedro Salazar and José Woldenberg. 2000. La mecánica del cambio político en México: elecciones, partidos y reformas. Mexico City: Cal y Arena.

Benton, Allyson. 2012. “Bottom-Up Challenges to National Democracy: Mexico's (Legal) Subnational Authoritarian Enclaves." Comparative Politics 44(3): 253-271.

Bloomberg. July 1, 2020. “López Obrador Is Making Mexico's Tragedy Worse." Retrieved 9 July 2021 from https://www.bloomberg.com/opinion/articles/2020-07-01/ amlo-s-austerity-is-making-mexico-s-economic-tragedy-worse.

Bruhn, Kathleen. 2010. Taking on Goliath: The Emergence of a New Left Party and the Struggle for Democracy in Mexico. University Park: Pennsylvania State University Press.

Buendía \& Márquez. 2021. "Aprobación presidencial." Retrieved 3 June 2021 from http:/ / buendiaymarquez.org/wp-content/uploads/2021/03/2102_APROBACION.pdf.

Cámara de Diputados. 2021. "Reformas Constitucionales y legales aprobadas por la LXIV Legislatura." Retrieved 15 March 2021 from http://www.diputados.gob.mx/LeyesBiblio/legis/reflxiv.htm.

Canes-Wrone, Brandice. 2001. "The President's Legislative Influence from Public Appeals." American Journal of Political Science 45(2): 313-329.

Carpizo, Jorge. 2002. El presidencialismo mexicano. Mexico City: Siglo XXI.

Casar, María A. 1996. "Las bases político-institucionales del poder presidencial en México." Política y Gobierno 3(1): 61-92.

Coppedge, Michael, Angel Alvarez and Claudia Maldonado. 2008. “Two Persistent Dimensions of Democracy: Contestation and Inclusiveness." The Journal of Politics 70(3): 632-647.

Cornelius, Wayne. 1999. "Subnational Politics and Democratization: Tensions Between Center and Periphery in the Mexican Political System." In Subnational Politics and Democratization in Mexico, edited by Wayne Cornelius, Todd Eisenstadt and Jane Hindley. San Diego: University of California, 3-16.

Cornelius, Wayne. 2000. "Blind Spots in Democratization: Sub-national Politics as a Constraint on Mexico's Transition." Democratization 7(3): 117-132.

Cosío Villegas, Daniel. 1972. El sistema político mexicano. Mexico City: Joaquín Mortiz.

Dahl, Robert. 1971. Polyarchy: Participation and Opposition. New Haven: Yale University Press.

Dahl, Robert. 1982. Dilemmas of Pluralist Democracy. New Haven: Yale University Press.

Diamond, Larry. 1996. “Toward Democratic Consolidation." In The Global Resurgence of Democracy, $2^{\text {nd }}$ ed., edited by Larry Diamond and Marc F. Plattner. Baltimore: Johns Hopkins University Press.

Downs, Anthony. 1957. An Economic Theory of Democracy. New York: Harper.

Flamand, Laura. n.d. "Federalism and Covid: Managing the health and economic crisis in the Mexican federation." Retrieved 19 January 2021 from https://forumfed.org/publications/8908/.

Gibson, Edward. 2013. Boundary Control: Subnational Authoritarianism in Federal Democracies. New York: Cambridge University Press.

Giraudy, Agustina. 2010. "The Politics of Subnational Undemocratic Regime Reproduction in Argentina and Mexico." Journal of Politics in Latin America 2(2): 53-84.

Greene, Keneth. 2007. Why Dominant Parties Lose: Mexico's Democratization in Comparative Perspective. New York: Cambridge University Press.

Guardado, Jenny. 2009. "La identidad partidista en México." Política y Gobierno Volumen temático 2009: 137-175. 
Gurría, Ángel. 2020. “Gender Equality and the Empowerment of Women for Inclusive Growth in Mexico." Retrieved 21 April 2021 from https://www.oecd.org/about/secretary-general/gender-equality-and-empowerment-of-women-for-inclusive-growth-mexico-january-2020.htm

Habermas, Jürgen. 1991. The Structural Transformation of the Public Sphere: An Inquiry Into a Category of Bourgeois Society. Cambridge: MIT Press.

Hager, Gregory, L. and Terry Sullivan. 1994. "President-centered and Presidency-centered Explanatiosn of Presidenctial Public Activity." American Journal of Political Science 38(4): 1079-1103.

Howell, William G. 2003. Power without Persuasion: The Politics of Direct Presidential Action. Princeton: Princeton University Press.

Huntington, Samuel P. 1968. Political Order in Changing Societies. New Haven: Yale University Press.

IMF. 2021. "Policy Responses to Covid-19." Retrieved 9 July 2021 from https:/ /www.imf. org/en/Topics/imf-and-covid19/Policy-Responses-to-COVID-19.

INEGI. 2020. "Employment and occupation." Retrieved 10 December 2020 from https:/ / www.inegi.org.mx/temas/empleo/.

INEGI. 2021. “Encuesta Nacional de Cultura Cívica (ENCUCI) 2020." Retrieved 9 July 2021 from https://www.inegi.org.mx/programas/encuci/2020/.

Integralia. 2020. "The First 100 Days of AMLO's Presidency". Retrieved 16 February 2021 from https://integralia.com.mx/web/wp-content/uploads/2019/11/Integralia-Consultores-The-First-100-Days-of-AMLOs-Presidency-2.pdf.

Karlinsky, Ariel and Dmitry Kobak. 2021. “The Word Mortality Dataset: Tracking excess mortality across countries during the COVID-19 pandemic." medRxiv [Preprint]. June 4, 2021.

Latinobarómetro. 2018. "Informe." Retrieved 9 July 2021 from https://www.latinobarometro.org/latContents.jsp.

Levitsky, Steven, and Lucan A. Way. 2010. Competitive Authoritarianism: Hybrid Regimes After the Cold War. New York: Cambridge University Press.

Levitsky, Steven. 2003. Transforming Labor-Based Parties in Latin America: Argentine Peronism in Comparative Perspective. New York: Cambridge University Press.

Loaeza, Soledad. 2020, May 1. "Un Presidente sin Estado." Nexos. Retrieved 25 May 2021 from https://soledadloaeza.nexos.com.mx/2020/05/un-presidente-sin-estado/.

Lujambio, Alonso. 2000. El poder compartido: Un ensayo sobre la democratización mexicana. Mexico City: Océano.

Mainwaring, Scott and Timothy R. Scully. 1995. "Party systems in Latin America." In Building Democratic Institutions: Party Systems in Latin America, edited by Scott Mainwaring and Timothy R. Scully Stanford: Stanford University Press, 1-34.

Mainwaring, Scott and Mathew Shugart. 2002. "Presidencialismo y democracia en América Latina: revisión de los términos del debate." In Presidencialismo y democracia en América Latina, edited by Scott Mainwaing and Matthew S. Shugart. Buenos Aires: Paidós.

Martí, Salvador, Reynaldo Ortega and Fernanda Somuano. 2011. La democracia en México: Un análisis a 10 años de la alternancia. Barcelona: Bellaterra.

Merino, Mauricio. 2003. La transición votada: Crítica a la interpretación del cambio político en México. Mexico City: Fondo de Cultura Económica.

Mexico News Daily. 2020, June 23. "AMLO vows to be elections 'guardian;' elections body says 'that's our job". Retrieved February $5^{\text {th }} 2021$, at: https://mexiconewsdaily.com/ news/amlo-vows-to-be-elections-guardian/.

Mexico News Daily. 2021, January 8. "Critics see setback for democracy in elimination of autonomous agencies". Retrieved 29 January 2021 from https:/ / mexiconewsdaily.com/ news/critics-see-setback-for-democracy/.

Morgenstern, Scott, John Polga Hecimovich and Sarah Sahir Rosenfield. 2013. "Tall, Grande, or Venti: Presidential Powers in the United States and Latin America." Comparative Political Studies 5(2): 1-28.

Negretto, Gabriel. 2006. "La reforma constitucional en México. Apuntes para un debate futuro." Política y Gobierno 13(2): 361-392. 
OECD. May 2021. “Economic Forecast Summary.” Retrieved 9 July 2021 from https:/ /www. oecd.org/economy/mexico-economic-snapshot/.

O'Donnell, Guillermo and Philippe Schmitter. 1986. Transitions from Authoritarian Rule: Tentative Conclusions about Uncertain Democracies. Washington: Woodrow Wilson International Center for Scholars / John Hopkins University Press.

Oraculus. n.d. "Aprobación Presidencial. Poll of Polls." Retrieved 14 April 2021 from https://oraculus.mx/aprobación-presidencial/.

Palma, Esperanza and María Cristina Osornio. 2020. “Competencia, fragmentación y volatilidad electoral en México: formatos de competencia a nivel nacional y subnacional." In México 2018: elecciones, partidos y nuevos clivajes sociales, edited by Esperanza Palma y Sergio Tamayo. Mexico City: Universidad Autónoma Metropolitana, 23-60.

Pardo, María del Carmen and Mauricio Dussage-Laguna. 2017. "Policy-analysis in Autonomous Agencies." In Policy Analysis in Mexico, edited by José-Luis Méndez and Mauricio Dussage-Laguna. Bristol: Policy Press, 87-107.

Penfold, Michael. 2010. "La democracia subyugada: el hiperpresidencialismo venezolano." Revista de Ciencia Política 30(1): 21-40.

Petersen, German. 2018. "Elites and turnovers in authoritarian enclaves: Evidence from Mexico." Latin American Politics and Society 60(2): 23-40.

Przeworski, Adam. 1975. "Institutionalization of voting patterns, or is mobilization the source of decay?" American Political Science Review 69: 49-67.

Putnam, Robert. 1993. Making Democracy Work. Civic Traditions in Modern Italy. Princeton: Princeton University Press.

Rose-Ackerman, Susan, Diane A. Desierto and Natalia Volosin. 2011. "Hyper-presidentialism: Separation of Powers without Check and Balances in Argentina and Philipines." Berkeley Journal of International Law 29(1): 246-333.

Ruiz Healy, Eduardo. 2020, December 2. "La gente siente cariño por AMLO y sus opositores no lo entienden." Retrieved 24 March 2021 from https://www.eleconomista. com.mx/opinion/La-gente-siente-carino-por-AMLO-y-sus-opositores-no-lo-entienden-20201201-0156.html.

Russell, Benjamin. 2019, November 26. “The Change Brewing in Mexico's Courts," Retrieved February 16, 2021 from https:/ / www.americasquarterly.org/article/the-changebrewing-in-mexicos-courts/.

Sánchez-Talanquer, Mariano. 2020. "Mexico 2019: Personalistic Politics and Neoliberalism from the Left." Revista de Ciencia Politica 40(2): 401-430.

Sartori, Giovanni. 2005 [1976]. Parties and Party Systems: A Framework for Analysis. New York: Cambridge University Press.

Schedler, Andreas. 2006. Electoral Authoritarianism: The Dynamics of Unfree Competition. Boulder: Lynne Rienner Publishers.

Sonnleitner, Willibald. 2020. La reconfiguración territorial de las fuerzas políticas mexicanas: geografía de la fragmentación, el colapso y la recomposición del sistema de partidos (2012-2018). Foro Internacional 60(2): 451-500.

Suprema Corte de Justicia de la Nación. n.d. "Supreme Court of Mexico." Retrieved 9 July 2021 from https://www.scjn.gob.mx/sites/default/files/pagina/documentos/2019-08/SCJNVisitorsGuideVF.pdf.

Tilly, Charles. 2007. Democracy. New York. Cambridge University Press.

Tocqueville, Alexis. 1945 [1835]. Democracy in America. New York: A. Knopf.

Weyland, Kurt. 2021. How Populism Corrodes Latin American Parties. Journal of Democracy 32(4).

Zaga, Daniel, Alessandra Ortiz and Jesús Leal Trujillo.. 2020, December 21. "Mexico Rocky Road to Recovery." Deloitte. Retrieved 5 February 2021 from https:/ /www2.deloitte. $\mathrm{com} / \mathrm{us} / \mathrm{en} /$ insights/economy/americas/mexico-economic-outlook.html. 
German Petersen is associate professor of political science at ITESO, the Jesuit University of Guadalajara, Mexico. He specializes in comparative politics and his main areas of interest are democratization, political participation, corruption, anti-corruption and development, with focus on Mexico. Recent publications include Early Democratization, Corruption Scandals and Perceptions of Corruption: Evidence from Mexico (Democratization, 2021) and Elites and Turnovers in Authoritarian Enclaves: Evidence from Mexico (Latin American Politics and Society, 2018). E-mail: gpetersen@iteso.mx

Fernanda Somuano is associate professor of the Center for International Studies at El Colegio de México. Her research focuses on public opinion and political participation, civil society, subnational democratization processes in Mexico in comparative perspective. Recent publications include Participar o no participar: análisis tipológico de la participación ciudadana de los mexicanos (Revista de ciencia política, 2020, with Fernando Nieto) and Meet the Victim: Police Corruption, Violence, and Political Mobilization (Governance, 2021, with Aldo Ponce and Rodrigo Velázquez). Email: fsomuano@colmex.mx 